\title{
Modified Electrodes Prepared with Polyphenolic Film Containing Ruthenium Complex and Metal Ligand Anchored by Azo Covalent Bond
}

\author{
Juliana R. Steter, José O. Pontólio, Maria Lúcia A. M. Campos and José R. Romero* \\ Departamento de Química, Faculdade de Filosofia, Ciências e Letras de Ribeirão Preto, \\ Universidade de São Paulo, Av. Bandeirantes 3900, 14040-091 Ribeirão Preto-SP, Brazil
}

\begin{abstract}
Este trabalho apresenta dois novos eletrodos de grafite modificados que foram preparados via polimerização da função fenólica, previamente funcionalizada por grupos azo (bipiridina e 2-metoxipiridina), que atuam como estruturas chaves para a ancoragem de ligantes de interesse. As sínteses dos monômeros BAP (4-([2,2']bipiridinil-4-ilazo)-fenol) e PAPmetóxi (5-(4-hidroxifenilazo)piridin-2-metóxi) foram simples, deram bons rendimentos e os monômeros foram facilmente eletropolimerizados, levando à formação de eletrodos modificados (EM) química e mecanicamente estáveis. Em solução aquosa e em circuito aberto, o EM PAP-metóxi formou complexos estáveis com $\mathrm{Cd}, \mathrm{Cu}$ e $\mathrm{Pb}$, produzindo picos redox bem definidos, demonstrando o grande potencial deste eletrodo para futuras aplicações analíticas. O monômero BAP foi utilizado para produzir um complexo de rutênio (BAP-Ru) que foi eletropolimerizado entre $+0.50 \mathrm{e}+0.75 \mathrm{~V}$ ( vs. $\mathrm{Ag} / \mathrm{AgCl}$ ), permitindo que o rutênio permanecesse disponível para atuar como catalisador. $\mathrm{O}$ EM BAP-Ru oxidou seletivamente uma variedade de substratos orgânicos dando produtos com rendimentos próximos ou melhores que aqueles obtidos por catálise homogênea com complexos de rutênio similares, ou quando este tipo de catalisador é impregnado em pasta de carbono.
\end{abstract}

This work presents two new modified carbon electrodes which were prepared via the polymerization of a phenolic moiety previously functionalized with azo groups (bipyridine and 2-methoxypyridine) as key structures to anchor the desired ligands. The syntheses of BAP (4-([2,2']-bipyridinyl-4-ylazo)-phenol) and PAPmethoxy (5-(4-hidroxyphenylazo) pyridin-2-methoxy) were simple to perform, gave good yields and the monomers were easily electropolymerized resulting in chemically and mechanically stable modified electrodes. The PAPmethoxy $\mathrm{ME}$ formed stable complexes with $\mathrm{Cd}, \mathrm{Cu}$ and $\mathrm{Pb}$ in aqueous media at open circuit and produced well defined redox peaks, showing good potential for future analytical applications. The BAP monomer was used to produce a ruthenium complex (BAP-Ru) which was electropolymerized from +0.50 to $+0.75 \mathrm{~V}$ ( $v s$. $\mathrm{Ag} / \mathrm{AgCl}$ ) to leave the ruthenium available to act as a catalyst. The BAP-Ru ME was able to oxidize a variety of organic substrates with good selectivity. The yields obtained were either similar to, or better than, those obtained by homogeneous catalysis using a similar ruthenium catalyst or when this type of catalyst is supported in a carbon paste electrode.

Keywords: metal complexation, polyphenolic film, ruthenium

\section{Introduction}

The modification of an electrode surface by an organic polymeric film functionalized either by a metal complex or a metal ligand has been broadly studied due to its applications on light absorption involving electron and energy transfer ${ }^{1-5}$ and electrocatalysis, ${ }^{6-9}$ as well as for its use as a sensor for trace analysis in a variety of media. ${ }^{10-13}$

*e-mail: jrromero@ffclrp.usp.br
Phenyl allyl ethers derived from aromatic phenols can be easily electrochemically polymerized on carbon electrodes to produce a modified electrode with good mechanical and chemical stability. ${ }^{6,14-19}$ The electropolymerization of the monomer to form this type of film can be performed by doing scans within a potential interval less positive than the oxidation potential of the functional group to preserve the key moiety.

Modified electrodes (ME) can also be prepared using phenol compounds functionalized with azo groups as the key structure to anchor a variety of ligands which can be used 
for different applications. Phenol electropolymerization has been widely studied, ${ }^{20,21}$ and more recently a polymerization mechanism has been proposed for tyramine. ${ }^{22}$ The advantage of producing this type of monomer is that phenol is easily azo-functionalized with commercially available ligands of different types. This is possible because most phenol compounds are heteroaromatics and reactive for an azoic coupling bond.

We have recently produced in our laboratories carbon stick and stainless steel modified electrodes by introducing an azo covalent bond in the para position of the allylbenzene ring to anchor a quinolin-8-ol group, which is a well known transition metal ligand. ${ }^{6,23}$ This type of film has the advantage of having a large potential window available where metal complexes can be reduced.

Ruthenium complexes are being widely studied to promote organic substrate oxidation, especially using electrocatalytic methods, since this metal is easily re-oxidized at low anodic potentials. However, in homogeneous catalysis, it is difficult to isolate the complex from the oxidation products, which results in a loss of efficiency and a poor recovery of the catalyst for further use. Therefore it would be highly desirable to bind the catalyst to a solid working electrode, since after the electrocatalysis the modified electrode can be manually removed from the reaction medium.

This work reports the synthesis and characterization of two monomers BAP (4-([2,2']bipyridinyl-4-ylazo)-phenol) and PAPmethoxy (5-(4-hidroxyphenylazo)pyridin-2methoxy), prepared from bipyridin and pyridine-2-methoxy ligands anchored via azo covalent bonds to the phenolic ring. The monomer PAPmethoxy was polymerized over a carbon rod electrode which was then tested for trace metals complexation to evaluate its application as a sensor. The monomer BAP was complexed with ruthenium and electropolymerized to form a new carbon rod ME which was tested for the electro-oxidation of different organic substrates.

\section{Experimental}

\section{Equipment and reagents}

All the solutions were prepared using deionized water (Milli-Q, Millipore Inc., > 18M $\Omega$ ). The chemicals were of analytical grade and were purified when necessary. Bipyridine was acquired from Aldrich and 2-methoxypyridine was synthesized from 2-hydroxipyridine (ACROS).

The voltammetric equipment consisted of a 237A PAR potentiostat run by the software model 270 . The voltammetric experiments were carried out in a cylindrical cell (20 or $25 \mathrm{~mL}$ ) using $\mathrm{Ag} / \mathrm{AgCl}$ as the reference electrode and a platinum wire or gauze as the auxiliary electrode. The monomers were electropolymerized on either a $3 \mathrm{~mm}$ diameter glassy carbon electrode (GC) or a high purity carbon rod (99.9995\%; Alfa Aesar), $6.15 \mathrm{~mm}$ diameter and $102 \mathrm{~mm}$ long. The carbon rod ME was cleaned by hand, polishing it with an aqueous suspension of alumina (down to $0.05 \mu \mathrm{m})$. Proton nuclear magnetic resonance $\left({ }^{1} \mathrm{H}\right.$ NMR) spectra were obtained using a Brüker spectrometer model Advance DRX 400 (400 MHz) and FTIR spectra were recorded using a Perkin-Elmer spectrometer model RX series using liquid film or $\mathrm{KBr}$. The UV-Vis absorption spectra were recorded at $25{ }^{\circ} \mathrm{C}$ on a spectrophotometer (8452A HP) coupled to a 89090 model accessory.

\section{Syntheses of the monomers}

The monomers BAP and PAPmethoxy were prepared in 4 main steps using bipyridine and 2-methoxypyridine as starting materials (Figure 1). The intermediates [2,2'] bipyridinyl- $N$-oxide and 2-methoxypyridin- $N$-oxide were nitrated. ${ }^{24}$ In the electrophilic substitution reactions, the $\mathrm{N}$-oxides were $p$-dirigent for bipirydine and $m$-dirigent for 2-methoxypyridin. ${ }^{24}$ The nitro-intermediates were reduced firstly with hydrazine ${ }^{25}$ and then with acetic acid in the presence of iron $(\mathrm{HAc}) / \mathrm{Fe}$, producing the corresponding substituted amine. ${ }^{26}$ The derived azoic compounds were obtained by azoic coupling reactions between the amines and phenol. ${ }^{27}$

\section{Preparation of the poly-(PAPmethoxy) film and its metal complexation}

Initially, the co-solvent proportion and the monomer concentration, as well as the voltammetric parameters, were optimized to establish the best experimental conditions to prepare the ME. The monomer PAPmethoxy $(0.57 \mathrm{~g}$, $2.5 \times 10^{-4} \mathrm{~mol}$ ) was dissolved in a cell containing $15 \mathrm{~mL}$ of the support electrolyte $\mathrm{H}_{2} \mathrm{SO}_{4}\left(0.5 \mathrm{~mol} \mathrm{~L}^{-1}\right): \mathrm{CH}_{3} \mathrm{CN}$ (3:7). The film characterization was initially performed using a GC electrode within a potential interval from -1.0 to $+2.0 \mathrm{~V}$ at a scan rate of $25 \mathrm{mV} \mathrm{s}^{-1}$. The electropolymerization on the carbon rod electrode $(0.46 \mathrm{~g}, 2.0 \mathrm{mmol}$ for the monomer $)$ was performed from +0.70 to $+1.2 \mathrm{~V}$ at $10 \mathrm{mV} \mathrm{s}^{-1}$.

The metal complexation was done at open circuit by immersing 9 freshly prepared carbon rod MEs for $30 \mathrm{~min}$ in individual metal solutions of $\left(\mathrm{Cd}\left(\mathrm{NO}_{3}\right)_{2}\right.$ or $\mathrm{Pb}\left(\mathrm{NO}_{3}\right)_{2}$ or $\mathrm{CuSO}_{4}$ ) at 3 different concentrations: 0.5, 1.5 and $10 \mu \mathrm{mol} \mathrm{L}{ }^{-1}$. After this procedure, each ME was rinsed with deionized water and later placed into a voltammetric cell containing $15 \mathrm{~mL}$ of $\mathrm{KCl} 0.1 \mathrm{~mol} \mathrm{~L}^{-1}$. The metal reduction 


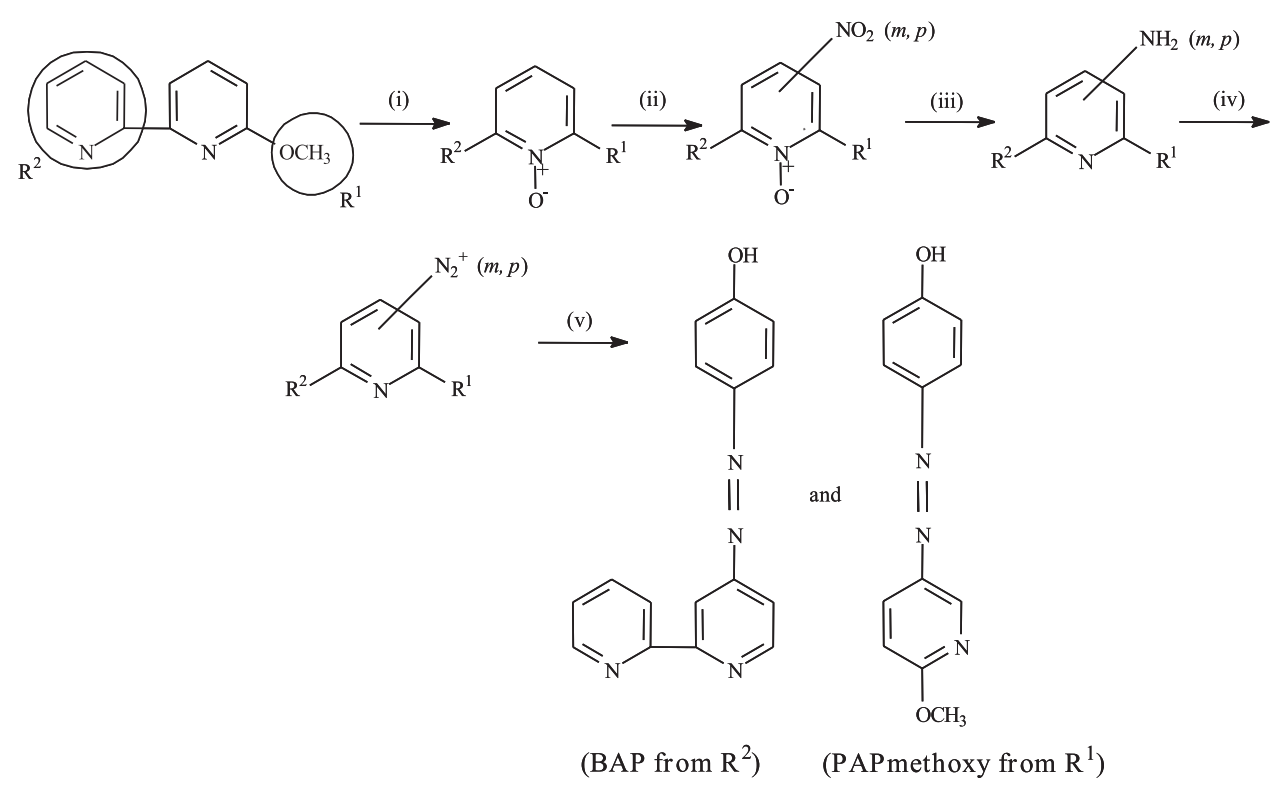

Figure 1. Schematic representation of the synthesis of PAPmethoxy $\left(\mathrm{R}_{1}\right.$ ): (i) peracetic acid reflux for $24 \mathrm{~h}$; (ii) $\mathrm{H}_{2} \mathrm{SO}_{4} / \mathrm{HNO}_{3}$, reflux for $6 \mathrm{~h}, 87.5 \%$ (overall for the two steps); (iii) $\mathrm{HAc} / \mathrm{Fe}$ reflux for $80 \mathrm{~min}, 49 \%$; (iv) $\mathrm{NaNO}_{2} / \mathrm{HCl} / \mathrm{H}_{2} \mathrm{O}, 0-5{ }^{\circ} \mathrm{C}$ and (v) $\mathrm{PhOH} / \mathrm{NaOH}, 40 \mathrm{~min}, 70 \%$; and BAP (R $)$ : (i) $\mathrm{MCPBA}$, $\mathrm{CH}_{2} \mathrm{Cl}_{2}, 14 \mathrm{~h}, 76 \%$; (ii) $\mathrm{H}_{2} \mathrm{SO}_{4} / \mathrm{HNO}_{3}$, reflux for $6 \mathrm{~h}, 50 \%$; (iii) $\mathrm{Pd} / \mathrm{C}$ (10\%), $\mathrm{NaBH}_{4}, \mathrm{CH}_{3} \mathrm{OH}, 2 \mathrm{~h}, 65 \%$; (iv) $\mathrm{NaNO}_{2} / \mathrm{HCl}_{2} / \mathrm{H}_{2} \mathrm{O}, 0-5{ }^{\circ} \mathrm{C}$ and (v) $\mathrm{PhOH} / \mathrm{NaOH}$, $40 \mathrm{~min}, 15 \%$. For PAPmethoxy the spectra data are: ${ }^{1} \mathrm{H}$ NMR (DMSO- $d$ ) $\delta(\mathrm{ppm}): 4.00(\mathrm{~s}, 3 \mathrm{H}), 6.92(\mathrm{~d}, 2 \mathrm{H}), 6.99(\mathrm{~d}, 1 \mathrm{H}), 7.80(\mathrm{~d}, 2 \mathrm{H}), 8.10(\mathrm{~d}, 1 \mathrm{H}), 8.72$ $(\mathrm{s}, 1 \mathrm{H}), 10.32$ (s broad $\mathrm{OH}, 1 \mathrm{H})$; FTIR $(\mathrm{KBr})$, neat $\left(\mathrm{v} / \mathrm{cm}^{-1}\right)$ : $3308(\mathrm{OH}), 3048(\mathrm{C}-\mathrm{H}$ aromatic ring absorption), 1600 and $1455(\mathrm{C}=\mathrm{C})$ and $(\mathrm{C}=\mathrm{N}), 1474$, $(\mathrm{N}=\mathrm{N}), 1236(\mathrm{C}-\mathrm{O}-\mathrm{C})$ and $1040(\mathrm{C}-\mathrm{O}-\mathrm{C})$. For BAP: ${ }^{1} \mathrm{H}$ NMR (DMSO- $d$ ) $\delta(\mathrm{ppm}): 8.50-9.20(\mathrm{~m}, 4 \mathrm{H}), 8.2(\mathrm{~s}, 1 \mathrm{H}), 7.9(\mathrm{~d}, 2 \mathrm{H}), 7.7(\mathrm{~s}, 1 \mathrm{H}), 7.6(\mathrm{~s}, 1 \mathrm{H}), 7.1$ $(\mathrm{d}, 2 \mathrm{H}), 4.6\left(\mathrm{~s}\right.$ broad OH, 1H). FTIR $(\mathrm{KBr})$, neat $\left(\mathrm{v} / \mathrm{cm}^{-1}\right): 3400(\mathrm{OH}), 1610(\mathrm{C}=\mathrm{C}), 1600(\mathrm{C}=\mathrm{N})$ e $1590(\mathrm{~N}=\mathrm{N})$.

and oxidation waves for each ME were recorded at a scan rate of $10 \mathrm{mV} \mathrm{s}^{-1}$.

\section{Preparation of the poly-(BAP) film}

After the optimization of the chemical and voltammetric parameters, the monomer BAP $(0.034 \mathrm{~g} ; 0.124 \mathrm{mmol})$ was dissolved in a cell containing $15 \mathrm{~mL}$ of the support electrolyte $\mathrm{H}_{2} \mathrm{SO}_{4}\left(0.5 \mathrm{~mol} \mathrm{~L}^{-1}\right): \mathrm{CH}_{3} \mathrm{CN}$ (6:4). The GC coating was performed by scanning from 0.0 to $2.0 \mathrm{~V}$ at $25 \mathrm{mV} \mathrm{s}^{-1}$.

Preparation of the cis- $\left[\mathrm{Ru}(\mathrm{BAP})(\mathrm{bpy})\left(\mathrm{PPh}_{3}\right)\left(\mathrm{OH}_{2}\right)\right]\left(\mathrm{ClO}_{4}\right)_{2}$ complex and its polymerization

The $c i s$ - $\left[\mathrm{Ru}(\mathrm{BAP})(\mathrm{bpy})\left(\mathrm{PPh}_{3}\right)\left(\mathrm{OH}_{2}\right)\right]\left(\mathrm{ClO}_{4}\right)_{2}(\mathrm{BAP}-\mathrm{Ru})$ complex was synthesized following a procedure pre iously described. ${ }^{18}$ FTIR (neat $\left./ \mathrm{cm}^{-1}\right) 3448\left(\mathrm{H}_{2} \mathrm{O}\right.$ and phenolic $\mathrm{OH}$ ); 2918 and 2738 (pyridil and phenyl $\mathrm{CH}$ ); 1618 and $1436(\mathrm{C}=\mathrm{C}$ and $\mathrm{C}=\mathrm{N}) ; 1092\left(\mathrm{PPh}_{3}\right) ; 696$ (pyridil out of plane $\mathrm{CH}$ absorption). UV-Vis $\left(\lambda_{\max } / \mathrm{nm}\right): 230(\mathrm{PhOH})$; 232 (pyridine); $291\left(\mathrm{PPh}_{3}\right)$ and $450(\mathrm{Ru}-\mathrm{O})$.

The poly-(BAP-Ru) film was electropolymerized on the carbon rod electrode using $0.074 \mathrm{~g}(0.073 \mathrm{mmol})$ of the complex dissolved in $15 \mathrm{~mL}$ of a TBAP/ $\mathrm{CH}_{2} \mathrm{Cl}_{2}$ $0.1 \mathrm{~mol} \mathrm{~L}^{-1}$ solution. The potential interval used was from
+0.50 to $+0.75 \mathrm{~V}$ at $25 \mathrm{mV} \mathrm{s}^{-1}$. The film characterization was performed using a $\mathrm{GC}$ electrode.

\section{Electrooxidation of organic substrates}

Initially, 4 carbon rod electrodes hanging from a copper support were submersed in the BAP-Ru complex solution for electropolymerization. The total area obtained was $53.84 \mathrm{~cm}^{2}$. The substrates tested were safrol, isosafrol, benzylic alcohol, phenyl ethyl alcohol and ethyl benzene dissolved in a phosphate aqueous buffer $\left(0.05 \mathrm{~mol} \mathrm{~L}^{-1}\right)$ at $\mathrm{pH}$ 7. An aliquot of $100 \mathrm{~mL}$ of each solution $\left(0.1 \mathrm{~mol} \mathrm{~L}^{-1}\right)$ was electrooxidized at a controlled potential $(+1.8 \mathrm{~V})$. The loss of substrate or the formation of products with time was monitored by the absorption in the corresponding wave length within the UV-Vis range.

\section{Results and Discussion}

The synthetic route proposed here was carried out using commercially available reagents and a small number of steps to produce the monomers PAPmethoxy and BAP with good yields: $70 \%$ and $37 \%$, respectively. The type of azo bond employed in this work has been previously used to anchor a quinolin moiety to complex transition metals. ${ }^{6}$ The synthesis of the BAP-Ru complex was performed by 
complexing $\mathrm{RuCl}_{3}$ on the bipyridine moiety ${ }^{18}$ and then substituting the chlorine atoms by triphenilphosphine and aqua. The total yield obtained was $65.4 \%$.

Firstly, the PAPmethoxy monomer was polymerized on the GC electrode to characterize the film (Figure 2A). The oxidation peak observed at $+0.70 \mathrm{~V}$ corresponds to the phenolic group, ${ }^{20,21}$ which would allow for the formation of the film. The peaks above $+0.70 \mathrm{~V}$ probably correspond to the oxidation of the ligand itself and therefore such positive potentials should be avoided when preparing the ME. Therefore, the electropolymerization on the carbon rod electrode was performed over the phenol oxidation potential range $(+0.750$ to $+1.025 \mathrm{~V})$, with electrical passivation taking place after 10 scans (Figure 2B). This type of polymerization permits the bidental ligand to remain unaltered and therefore available for metal complexation. Another important point is that there is a large potential range below $+1.0 \mathrm{~V}$ that can be explored for the detection of reduction waves from complexed transition metals as shown for the ME cyclic voltammogram in Figure 3.

This ME showed to be mechanically and chemically stable. It could be rinsed, dried with a soft tissue and kept in a plastic bag for weeks until use.
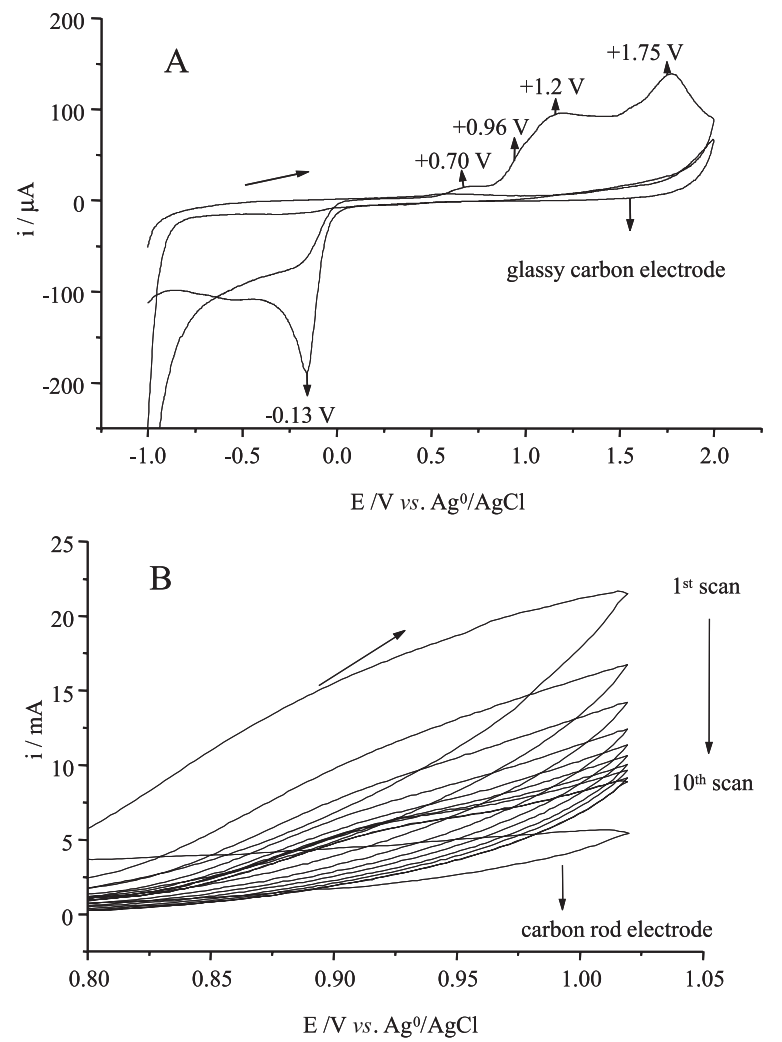

Figure 2. Cyclic voltammograms in the absence and in the presence of PAPmethoxy monomer in $\mathrm{H}_{2} \mathrm{SO}_{4}: \mathrm{CH}_{3} \mathrm{CN}$ solution. A) Electrochemical behavior of the monomer using a glassy carbon electrode when scanning from -1.0 to $+2.0 \mathrm{~V}$ at $25 \mathrm{mV} \mathrm{s}^{-1}$. B) Polymerization of the monomer on the carbon rod electrode, scanning from +0.775 to $+1.20 \mathrm{~V}$ at $10 \mathrm{mV} \mathrm{s}^{-1}$.
Figure 3 shows the PAP-methoxy ME regain its electroactivity after its contact with metal solutions at open circuit, producing clear redox waves. The reduction waves obtained for the three metals tested were well shaped and defined, corresponding to the following transitions: $\mathrm{M}^{0}-\mathrm{M}^{2+}$, $\mathrm{M}^{2+}-\mathrm{M}^{+}$and $\mathrm{M}^{+}-\mathrm{M}^{0}$ for $\mathrm{Cu}$ and $\mathrm{Cd}$, and $\mathrm{M}^{0}-\mathrm{M}^{+}$and $\mathrm{M}^{+}-\mathrm{M}^{2+}$ for $\mathrm{Pb}$. It is also possible to reduce the ligand during the potential scan, but it should not interfere in the complexed metal signal because the produced current is at $\mu \mathrm{A}$ levels, as showed in Figure 2A. The reduction and oxidation currents increased with metal concentration, demonstrating the capability of this ME to pre-concentrate metal ions such as $\mathrm{Cu}^{2+}, \mathrm{Cd}^{2+}$ and $\mathrm{Pb}^{2+}$ by complexation. It is likely that once the chemical $(\mathrm{pH}$, electrolyte concentration etc) and voltammetric conditions (scan rate, pulse mode, pulse height etc) are optimized, the ME sensitivity could be improved to reach lower concentrations. The proximity of some of the reduction peak potentials for different metals will also have to be addressed. The use of differential pulse and in situ pre-concentration are examples of voltammetric tools which could greatly improve selectivity and sensitivity for trace metal analysis ${ }^{27}$ and therefore enable the use of this electrode to quantify multi elements in natural samples.

As expected, the phenolic moiety from the BAP monomer was also oxidized at $+1.1 \mathrm{~V}$ (Figure 4). The electrochemical characterization for the BAP-Ru complex on the GC electrode showed that the ruthenium redox waves were all above $+0.90 \mathrm{~V}$ (Figure 5A). The well defined peak seen in the voltammogram for the phenolic moiety oxidation in the BAP monomer (Figure 4) appears to be attenuated to a small shoulder shifted at around $0.70-0.80 \mathrm{~V}$ when employing the ruthenium complex (Figure 5A). This shift was very interesting, as it allowed the phenol polymerization to be performed between $+0.50 \mathrm{~V}$ and $+0.75 \mathrm{~V}$, thus preserving the electroactivity of the two ruthenium redox pairs (Figure 5B). A total of 10 scans were needed to passivate the carbon rod electrode with the film.

The BAP-Ru ME efficiency was tested using a fixed potential of $+1.8 \mathrm{~V}$ to oxidize several substrates. The concentrations of the substrates were monitored by the decay of the characteristic $\lambda_{\text {max. }}$ by UV spectroscopy. The following substrates were studied at the respective wavelengths: safrol $(286 \mathrm{~nm})$, isosafrol $(286 \mathrm{~nm})$, benzilic alcohol $(310 \mathrm{~nm})$, phenyl ethyl alcohol $(250 \mathrm{~nm})$, ethylbenzene $(246 \mathrm{~nm})$, cyclo-hexenol $(230 \mathrm{~nm})$ and toluene $(233 \mathrm{~nm})$. These substrates were chosen because of their structural variety and because most of them have been previously studied in homogeneous catalysis using similar ruthenium complexes. ${ }^{6,12,14-19}$

Based on the known extinction coefficient for each organic substrate it was possible to calculate the variation 

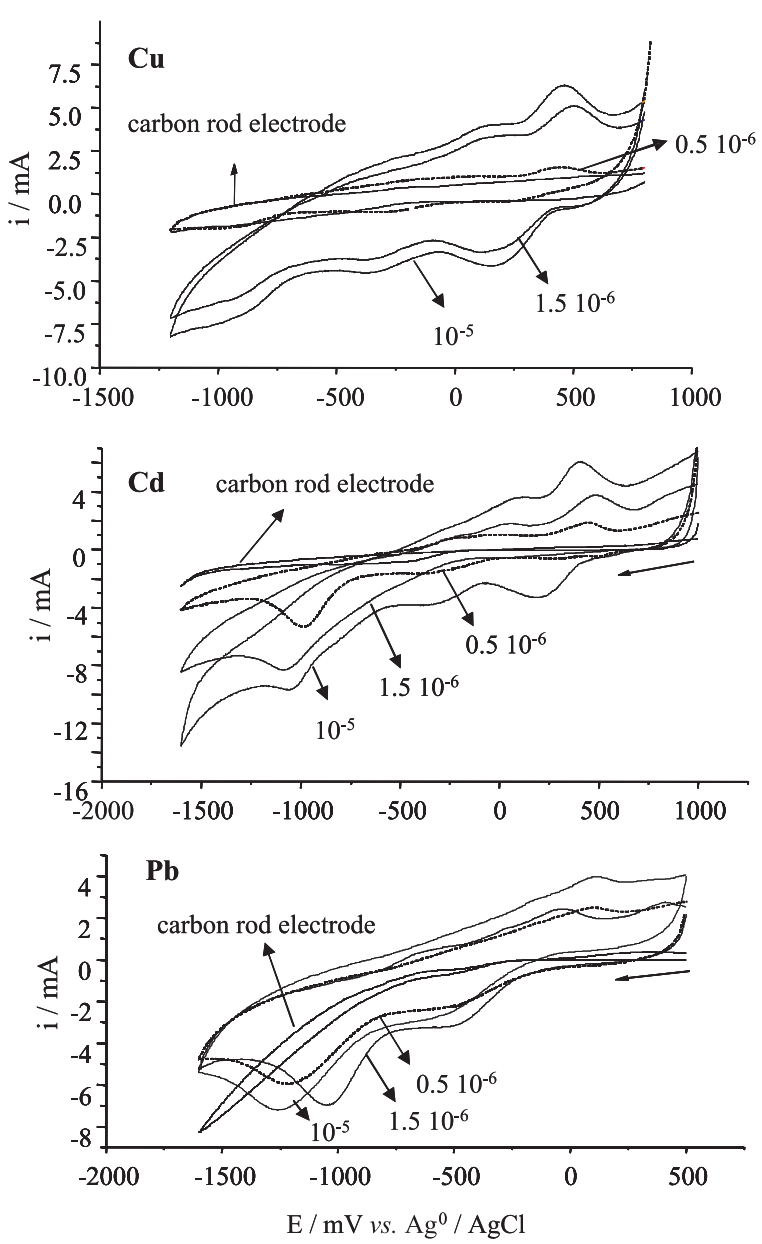

Figure 3. Voltammograms of the poly-PAPmethoxy ME electrode in $\mathrm{KCl} 0.1$ mol. $\mathrm{L}^{-1}$ when freshly prepared and after the complexation with $\mathrm{Cd}, \mathrm{Cu}$ and $\mathrm{Pb}$, at different concentrations, as indicated. The scans were recorded at $10 \mathrm{mV} \mathrm{s}^{-1}$.

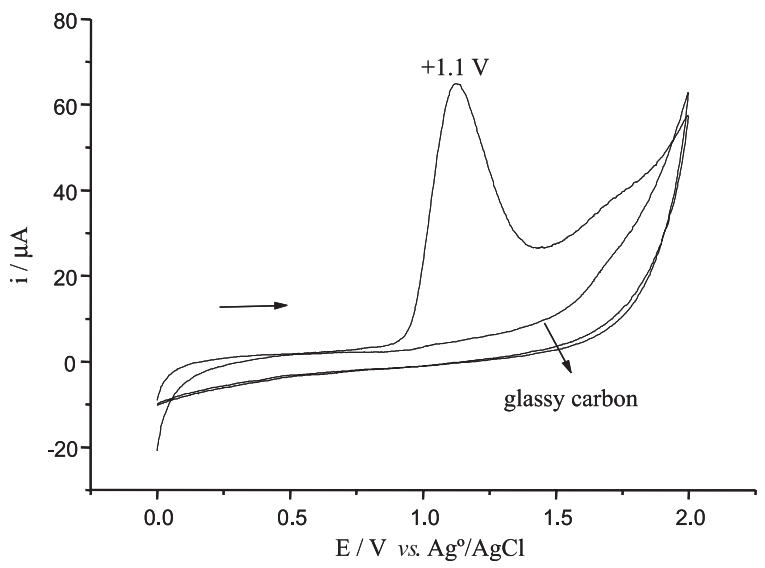

Figure 4. Cyclic voltammograms for the glassy carbon electrode in the absence and in the presence of the BAP monomer in $\mathrm{H}_{2} \mathrm{SO}_{4}: \mathrm{CH}_{3} \mathrm{CN}$ solution. The scan range was from 0.0 to $2.0 \mathrm{~V}$ at $25 \mathrm{mV} \mathrm{s}^{-1}$.

in concentrations as a function of time, and plotting those variables permitted to calculate the apparent constant speed, the product yield and the turnover number (Table 1). All the
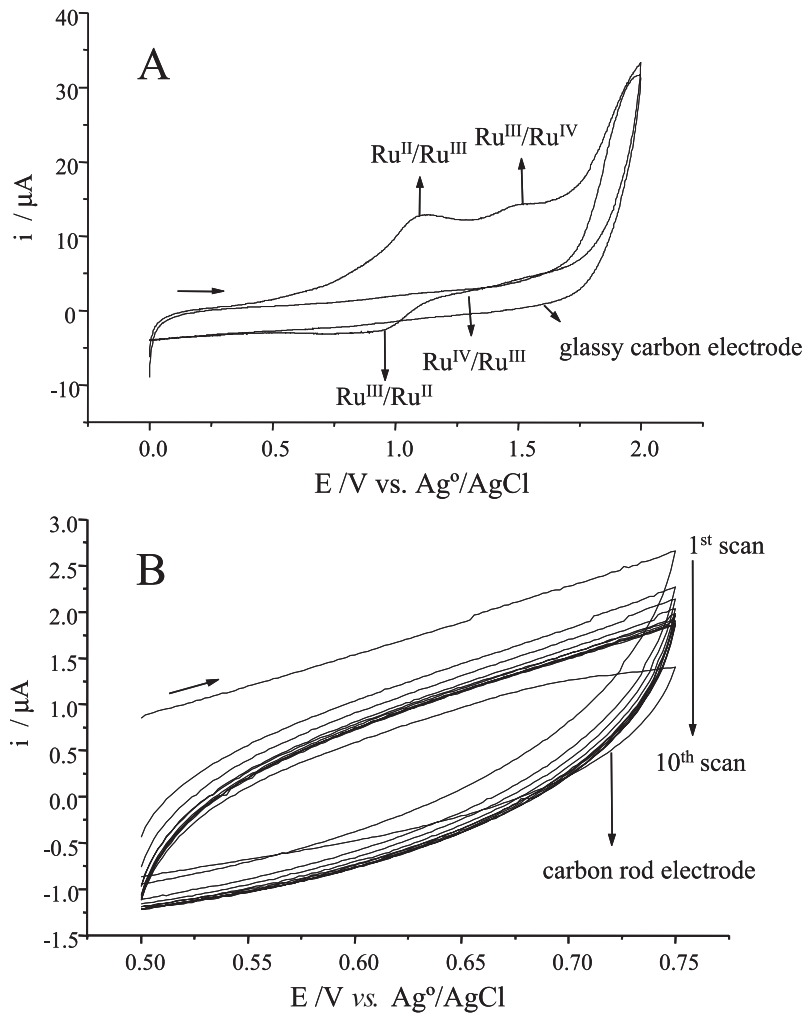

Figure 5. Cyclic voltammograms in the absence and in the presence of the BAP- $\mathrm{Ru}$ monomer in TBPA/ $\mathrm{CH}_{2} \mathrm{Cl}_{2}$ solution. A) Electrochemical behaviour of the monomer using a glassy carbon electrode when scanning from 0.0 to $+2.0 \mathrm{~V}$ at $25 \mathrm{mV} \mathrm{s}^{-1}$. B) Polymerization of the monomer on the carbon rod electrode, scanning from +0.50 to $+0.75 \mathrm{~V}$ at $25 \mathrm{mV} \mathrm{s}^{-1}$.

reactions studied in this work are considered to be pseudofirst order because it can be assumed that the catalyst concentration is in great excess. The relatively high turnover number shows the catalytic character of the film, while the apparent constant speed in the order of $10^{-2}-10^{-3} \mathrm{~min}^{-1}$ shows that the reactions are fast.

It is important to stress that safrol (which is a commercial natural product) produced piperonal (which is a synton of interest to the industry) due to the oxidation of the methylene between the benzenic ring and the double bond with the cleavage of the $\mathrm{CH}_{2}$-double bond and the loss of two carbons. The isosafrol also had the terminal methyl group oxidized to aldehyde; the $-\mathrm{CH}_{3}$ with a neighboring unsaturation can stabilize the radical cation generated to form an aldehyde. The oxidation of benzylic alcohol also led to an aldehyde. These results are interesting due to the selectivity of this process, since this type of electrocatalysis stops at the formation of aldehydes, not leading to carboxylic acids as most of the conventional methods do. It is interesting to note that the mild oxidation of an alkyl arene chain such as ethylbenzene led to the unexpected oxidation of the $-\mathrm{CH}_{2}$-neighboring a benzenic ring, resulting in acetophenone and not benzoic acid, as it would be expected for a conventional oxidation. 
Table 1. Kinetic and catalytic parameters for the substrates electrooxidation, and yield comparisons with published works

\begin{tabular}{|c|c|c|c|c|c|c|}
\hline Substrate & $\mathrm{k} /\left(\min ^{-1}\right)$ & Coulombs & Turnover & Yield* $(\%)$ & Yield (\%) & Products \\
\hline safrol & $2.47 \times 10^{-3}$ & 2978 & 4792 & 77 & $61^{19}$ & piperonal \\
\hline isosafrol & $2.84 \times 10^{-3}$ & 3116 & 5014 & 81 & $54^{19}$ & benzo[1,3]dioxol-5-propenal \\
\hline benzylic alcohol & $3.34 \times 10^{-3}$ & 3020 & 4890 & 80 & $78,{ }^{18} 42,,^{17} 36^{17}$ & benzaldehyde \\
\hline phenyl ethyl alcohol & $4.53 \times 10^{-3}$ & 2574 & 4168 & 68 & $81,{ }^{18} 98,{ }^{17} 66^{16}$ & acetophenone \\
\hline ethylbenzene & $2.60 \times 10^{-3}$ & 3103 & 4995 & 80 & $69^{18}$ & acetophenone \\
\hline cycle-hexenol & $1.82 \times 10^{-2}$ & 3440 & 5534 & 91 & - & cyclehexenone \\
\hline toluene & $0.89 \times 10^{-2}$ & 1992 & 3225 & 51 & $52,{ }^{16} 61^{16}$ & benzoic acid \\
\hline
\end{tabular}

* this work.

A possible intermediate of this reaction is phenylethyl alcohol, which can then be electrooxidized to acetophenone. The oxidation of ethylbenzene and acetophenone was also selective because the methylene was oxidized to a carbonyl group, while in the conventional methods the arenes are very often oxidized to benzoic acid. The phenyl ethyl alcohol obtained is an intermediary of this oxidation, since it gives the same product. The oxidation of cycle-hexenol had an excellent yield to form cycle-hexenone, and toluene produced benzoic acid, as expected.

Table 1 shows that the yields obtained for the substrates studied in this work were most of the time better than those obtained using similar ruthenium catalysts, either mixed homogeneously ${ }^{14-19}$ or supported in a carbon paste electrode. ${ }^{18}$ An important advantage of the catalyst immobilized on the ME is that it can be easily removed from the reaction vessel, it can be fully recovered, and the products can be extracted in a conventional way.

The mass of $\mathrm{Ru}$ deposited on the ME calculated by coulometry was ca. $1.610^{-7} \mathrm{~g}$. It is noteworthy that the mass ratio between the substrate and catalyst was in the order of $10^{3}$. The ME was reutilized 2 or 3 times in each experiment using the same substrate. The cyclic voltammogram performed after using the ME remained unchanged. All the above results point to the catalytic character of the $\mathrm{Ru}$ complex studied in this work. In order to achieve more accurate results, a new ME was prepared before using a different substrate.

In homogeneous catalysis with ruthenium complexes, the catalyst has to be isolated by conventional methods, which has several drawbacks, including an inefficient recovery. The greatest disadvantage of using carbon paste electrodes to support the catalyst ${ }^{18}$ is the poorer recovery of the catalyst when compared to the ME developed here.

\section{Conclusions}

The results presented in this work show that the functionalization of phenol compounds with azo groups as the key structure to anchor different ligands is simple and can produce MEs which are chemically and mechanically stable. The poly-PAPmethoxy carbon rod electrode was able to complex $\mathrm{Cd}, \mathrm{Cu}$ and $\mathrm{Pb}$ producing clear redox waves, which suggests that this electrode has a good potential to be applied as an electrochemical sensor. The BAP ruthenium complex ME showed that it can selectively oxidize some organic substrates giving interesting and unexpected products. This ruthenium complex immobilized on a solid surface had the advantage of giving similar or better yields than homogeneous catalysis using similar complexes, or when the complex was dispersed in a carbon paste electrode. Moreover, the catalyst used in this work could be easily removed from the reaction vessel and the ME reused.

\section{Acknowledgments}

The authors are grateful to CNPq and CAPES for the scholarship and financial support.

\section{References}

1. Malinauskas A.; Synth. Met. 1999, 107, 75.

2. Chardon-Noblat, S.; Deronzier, A.; Ziessel, R.; Zsoldos, D.; Inorg. Chem. 1997, 36, 5384.

3. Chardon-Noblat, S.; Cripps, G. H.; Deronzier, A.; Field, J. S.; Gouws, S.; Haines, R. J.; Southway, F.; Organometallics 2001, 20, 1668.

4. Rodrígues, M.; Romero, I.; Llobet, A.; Inorg. Chem. 2001, 40, 4150.

5. Eskelinen, E.; Haukka, M.; Venäläinen, T.; Pakkanen, T. A.; Wasberg, M.; Chardon-Noblat, S.; Deronzier, A.; Organometallics 2000, 19, 163.

6. Pontólio, J. O.; Ferranti N.; Campos, M. L. A. M.; Romero, J. R.; J. Electroanal. Chem. 2005, 584, 124.

7. Donnici, C. L.; Filho, D. H. M .; Moreira, L. L. C.; Reis, G. T.; Cordeiro, E. S.; Oliveira de, I. M. F.; Carvalho, S.; Paniago, E. B.; J. Braz. Chem. Soc. 1998, 9, 455.

8. Jones, R. A.; Roney, B. D.; Sasse, W. H.; Wade, K. O.; J. Chem. Soc. B 1967, 18, 107. 
9. Hilton, A.; Renouard, T.; Maury, O.; Le Bozec, H.; Ledoux, I.; Zyss, J.; Chem. Commun. 1999, 2521.

10. Takeuchi, R. M.; Santos, A. L.; Padilha, P. M.; Stradiotto, N. R.; Talanta 2007, 71, 771.

11. Wang, L.; Zhao, B. T.; Ye, B. X.; Electroanalysis 2007, 19, 923.

12. Heitzmann, M.; Bucher, C.; Moutet, J. C.; Pereira, E.; Rivas, B. L.; Royal, G.; Saint-Aman, E.; Electrochim. Acta 2007, 52, 3082.

13. Ugo, P.; Moretto, L.M.; Vezza, F.; ChemPhysChem 2002, 3, 917.

14. Campos, J. L.; De Giovani, W. F.; Romero, J. R.; Synthesis 1990, 597

15. Navarro, M.; De Giovani, W. F.; Romero, J. R.; Synth. Commun. 1990, 20, 399.

16. Carrijo, R. M. C.; Romero, J. R.; Synth. Commun. 1994, 24, 433.

17. Navarro, M.; Galembeck, S. E.; Romero, J. R.; De Giovani, W. F.; Polyhedron 1996, 15, 1531.

18. Lima, E. C.; Fenga, P. G.; Romero, J. R.; De Giovani, W. F.; Polyhedron 1996, 17, 313.

19. Steter, J. R.; Pontólio, J. O. S.; Costa, M. I. C. F.; Romero, J. R.; Polyhedron 2007, 26, 996.

20. Gattrell, M.; Kirk, D. W.; J. Electrochem. Soc. 1992, 139, 2736.
21. Gattrell, M.; Kirk, D. W.; J. Electrochem. Soc. 1993, 140, 903.

22. Terneiro, A. M.; Nabais, C.; Correia, J. P.; Fernandes, F. M. S. S.; Romero, J. R.; Abrantes, L. M.; J. Sol. State Electrochem. 2007, 11, 1059.

23. Khoo, S. B.; Guo, S. X.; J. Electroanal. Chem. 1999, 465, 102

24. Jones, R. A.; Roney, B. D.; Sasse, W. H.; Wade, K. O.; J. Chem. Soc. B 1967, 18, 107.

25. Hilton, A.; Renouard, T.; Maury, O.; Le Bozec, H.; Ledoux, I.; Zyss, J.; Chem. Commun. 1999, 2521.

26. Pham, M. C.; Tourillon, G.; Lacaze, P. C.; Dubois, J. E.; J. Electroanal. Chem. 1980, 111, 385.

27. Furniss, B.S.; Hannaford, A. J.; Smith, P. W. G.; Tatchell, A. R.; Vogel Textbook of Practical Organic Chemistry, Longman: London , $5^{\text {th }}$. ed., 1989.

28. van den Berg, C. M. G. In Chemical Oceanography; Riley, J. P., ed; Academic Press: London, 1989, ch. 51.

Received: September 25, 2007 Web Release Date: March 28, 2008

FAPESP helped in meeting the publication costs of this article. 